\title{
Aspects of Sustainable Development of Russian Regional Universities
}

\author{
E.Yu. Panasenkova*, S.S. Timofeeva, and O.S. Artemova \\ Irkutsk National Research Technical University, Lermontov st., 83, 664074 Irkutsk, Russia
}

\begin{abstract}
Modern universities present themselves as universities implementing the goals of sustainable development. The aim of this paper is to summarize the experience of universities in the world and Russia in the field of sustainable development and to work out a comprehensive program for the development of the Irkutsk National Research Technical University to achieve the goals of preserving the planet and creating a "green campus" taking into account regional aspects associated with the uniqueness of Lake Baikal. The paper considers the experience of a number of European universities and presents the directions of the longterm development program for the Irkutsk National Research University, resulting in the development of the Baikal region. In the work, we also consider aspects of the program taking into account the uniqueness of Lake Baikal.
\end{abstract}

\section{Introduction}

Universities in the 21 st century are not only a high level of education, but a tool to form a responsible society in the field of sustainable development. Currently, in most countries, one can observe a global ecological, economic, managerial and social crisis, which can be defined as a general civilizational crisis. The 2030 Agenda for Sustainable Development, officially adopted in 2015 by the UN General Assembly, is called upon to solve the global problems facing humanity [1].

Modern conditions are such that decision-making at almost all levels must be supported not only by economic indicators, but also by possible social and environmental risks arising from the implementation of these decisions in the future.

Territories are experiencing an acute shortage of qualified personnel and experts capable of solving the arising difficulties and problems. To make a transition to sustainable development, complex solutions are required, which could be implemented simultaneously in territories of different sizes and would combine innovative technological solutions and expert support. The leading role in the search for such solutions is assigned to research and educational centers. These are the leading higher educational institutions of the world. Universities are not only "personnel factories", but also carriers of the socio-cultural environment.

Education for sustainable development is considered today as a necessity [2], as one of the key conditions for an intellectual, inclusive, fair modernization of approaches to the

*Corresponding author: pey@istu.edu 
economy, to business activities, to the environmental management system, consumption, and the world order in general taking into account the interests of future generations. These are general guidelines adopted at the international and national levels.

Self-presentation of universities in terms of adhering to the goals of sustainable development provides a number of important advantages over other educational institutions: internationalization and international recognition, raising public awareness of sustainability issues [3], the ability to influence social change, as well as the ability to establish collaborations with science and businesses in the areas of sustainable development.

The aim of the paper is to summarize the experience of universities in the world and Russia in the field of sustainable development and to work out a comprehensive program for the development of the Irkutsk National Research Technical University to achieve the goals of preserving the planet and creating a "green campus" taking into account regional aspects associated with the uniqueness of Lake Baikal.

\section{Materials and Methods}

In the work with a retrospective of 10 years, we considered the world trends in the development of universities to achieve sustainable development goals based on the analysis of materials from Internet resources and university websites. Proclaiming and actual implementation of sustainable development entails the study of the adaptation of regional ecological and economic systems to socio-economic, natural-geographical and some other features of the Baikal region based on the theory of expert assessments. Using the example of the Irkutsk National Research Technical University, we considered the aspects of sustainable development of Russian regional universities.

\section{Results and Discussion}

The state policy of many countries is based on the UN sustainable development goals. In December 2019, the European Commission approved the European Green Deal, a roadmap for ensuring the sustainability of the economies in the European Union [4]. This document states that climate change and environmental degradation pose a threat to Europe and the entire world. The main goal of the document is to ensure that by 2050 the EU countries achieve zero total greenhouse gas emissions and zero total environmental pollution by switching from the use of fossil fuels to renewable energy sources and raw materials. Sustainable economic development goals can be achieved by investing in environmentally friendly technologies; creating cleaner, cheaper and healthier forms of transport; decarbonization of the energy sector; increasing the energy efficiency of buildings, improving global environmental standards.

Russia has adopted a number of documents aimed at implementing sustainable development goals [5-7], including a national action plan for adaptation to climate change. [5]. The Russian Federation recognizes the importance of the climate change problem and the consequences of these changes, which have a significant and growing impact on the socio-economic development of the country, living conditions and health of people, as well as on the state of economic facilities.

In following the directions of state policy in different countries, a significant role is assigned to universities, which can simultaneously develop research, educational and social areas.

Modern requirements for university graduates in Russia are prescribed not only by the Federal Law on Education, but also determined by employers. Thus, data from a survey of 
board members of 200 Russian companies in various sectors of the economy in 2019 [6] showed that in the global economy, businesses have to solve a wide range of social and environmental issues, and, therefore, their decision-making becomes integral to the task of maintaining financial stability in the long term. The principles of sustainable development define, create and protect intangible values. The lack of well-managed sustainability practices undermines the prospects for successful business development and creates significant reputational and financial risks for investors. $89 \%$ of respondents have already taken measures to integrate sustainability into the company's overall strategy, $81 \%$ believe that non-financial reporting increases investment attractiveness, and $17 \%$ have appointed a responsible for sustainable development at the level of the company's board of directors. Businesses recognize that pursuing sustainable development goals provides a competitive advantages in global markets. Consequently, university graduates must have competencies in this direction for further successful employment in large companies.

Universities of most European countries have been following this path for more than a decade. Sustainability implies the complex interaction of three factors: economic, social and environmental development. The development strategies of universities around the world are based exactly on them. Ways and methods of implementing sustainable development goals are determined by the specifics of a particular university. Let us look at some examples of universities in Europe and how they achieve their goals.

The University of Graz in its sustainable development strategy declares its impact on society and responsibility for the sustainable development of its students, employees and the local population. It is one of 17 other Austrian universities participating in the UniNEtZ (Universities and Sustainable Development Goals) project. Within the framework of the project, the University of Graz sponsors SDG 11 (sustainable development of cities and municipalities), coordinates, and harmonizes the activities of all parties involved in the implementation of this goal. In addition, the university implements the following goals: SDG 4 (high quality education), SDG 7 (affordable and clean energy), SDG 12 (responsible consumption and production patterns), and SDG 13 (measures to protect the climate).

In terms of social sustainability, the university presents itself as a barrier-free university that promotes the advancement of women, manages diversity and promotes the compatibility between work and family life.

In order to continuously improve its environmental performance, the University of Graz has been participating in a number of environmental programs since 2005, in particular ÖKOPROFIT (environmental project for the creation of an integrated environmental technology of the city of Graz), VDH "Consumption Half" aimed at implementing measures to reduce the university's greenhouse gas emissions in twice until 2030 [7].

Ranked in the top $1 \%$ of research universities in the world, the University of Helsinki is also concerned with sustainable development. The University of Helsinki, being the largest and oldest educational institution in Finland (founded in 1640), sees its main goals in the active development of society, creating prosperity and solving global problems [8]. This multidisciplinary university develops solutions to global problems based on sustainable development. The Helsinki Institute of Sustainability Science, HELSUS, which is part of the university, provides researchers with an inspiring interdisciplinary environment that encourages research, experiments and the search for the best possible solutions for a sustainable future. The policy of the university is as follows: "In the future, we wish to ensure the sustainability and responsibility of our activities in terms of ecology, society, finances and culture. Our campus development is increasingly consistently carried out in accordance with the principles of sustainable development."

The Helsinki Institute of Sustainability Science, HELSUS, coordinates research carried out at different faculties of the university in the following areas: "Production and Consumption" (sustainable bio-production and sustainable use of natural resources), 
"Global South" (a platform for exploring the conditions, limits and ways of ensuring sustainability in various developing countries of South and Southeast Asia), "Arctic" (environment, resources, as well as socio-political aspects), "Cities" (solving urgent modern urban problems not only in Finland, but also on a European and global scale) and "Theory and Methodology" (aimed at cross-cutting and interdisciplinary research in sustainable development). Significant attention is paid to the environmental friendliness of the campus and its activities; all processes necessary for teaching and research strive for the lowest possible greenhouse gas emissions and the highest possible efficiency in the use of materials.

The campus implements various environmental programs and engineering solutions, such as reducing energy and resource use and associated emissions, improving the efficiency of facilities, the Sustainable Transportation Program, its own solar power plant and the program of offsetting its carbon footprint.

UK universities are also focused on sustainable development. Thus, the University of Sussex has its own environmental policy and a range of programs aimed at minimizing its impact on the environment [9]. The goals and objectives of the university are determined to address the basic eight key areas: public engagement, construction and reconstruction, emissions and discharges, energy and water supply, health safety and well-being, sustainable supply, transport and waste management. They form the basis of an environmental management plan, in particular carbon footprint management in line with the Higher Education Funding Council for England (HEFCE) best practice guidelines.

Environmental projects on campus include installing solar photovoltaic panels on rooftops to reduce carbon emissions; automatic metering sensors that automatically catalog energy usage readings every 30 minutes, day and night, providing a clearer picture of campus energy use.

The university is conducting research to automate campus LED lighting systems that provide efficient indoor lighting with low energy consumption, improve interior lighting while reducing university energy consumption.

The University of Sussex has an interesting Sustainable Nutrition program. There are cafes and diners on campus that adhere to sustainability. To achieve this, SussexFood relies primarily on both local and organic products in its production. Food is delivered to the cafes in biodiesel vehicles, mainly from local suppliers to reduce $\mathrm{CO}_{2}$ emissions during delivery.

The university's transport policy is also aimed at reducing greenhouse gas emissions, using public transport by employees, and encouraging zero-emission vehicles - bicycles, electric and hybrid cars. For this, bike racks are located throughout the territory, and car parks are equipped with stands for charging electric vehicles. To further reduce dependence on fossil fuels and limit $\mathrm{CO}_{2}$ emissions, 8 of the 19 vehicles owned and used for maintenance on campus are electric vehicles.

Thus, world practice in the field of sustainable development shows that universities in different countries are full participants in the process. They shape their development strategies and research agenda based on the SDGs. And thus they are able to influence social change at the local and global level.

Russian universities have also joined this global trend. However, this direction of development for universities is still new, but it is necessary to be full participants in the global educational process and the development of academic mobility.

Participation in world educational rankings motivates Russian universities to create their own strategies based on the SDGs for international recognition and create a positive image of Russian education and scientific research.

The contribution of Russian universities to the implementation of sustainable development goals can be assessed using the Times Higher Education University Impact 
Rankings. This ranking covers 11 of the 17 UN SDGs. Among them: goal 3 - good health and well-being; goal 4 - quality education; goal 5 - gender equality; goal 8 - decent work and economic growth; goal 9 - industrialization, innovation and infrastructure; goal 10 reducing inequality; goal 11 - sustainable cities and towns; goal 12 - responsible consumption and production; goal 13 - combating climate change; goal 16 - peace, justice and strong institutions; goal 17 - partnership for sustainable development [10]. The overall THE University Impact Rankings include 462 universities from 76 countries. The ranking methodology is based on the analysis of three areas of university activities: research - the creation of knowledge in order to solve the most pressing global problems; socially oriented programs - direct activity of a university in society; management - resource management, the contribution of a university to education in a broad sense.

The most represented country in the ranking is Japan (41 universities), followed by the United States (31) and Russia (30). The ranking includes 30 Russian universities, 10 of them are universities participating in the Project 5-100.

The goal of the Project 5-100 is to maximize the competitive position of a group of leading Russian universities in the global market for educational services and research programs, which is currently impossible without the implementation of sustainable development goals at their sites. In the top hundred of the best universities in the THE University Impact Rankings: "good health and well-being" - Sechenov University (rank 84); "decent work and economic growth" - ETU "LETI" (rank 37); "industrialization, innovation and infrastructure" - NRNU "MEPhI" (rank 48). Among the universities leading in the ranking in the direction of "sustainable cities and towns" - SPbPU (rank 40); "reducing inequality" - TPU (rank 78). The contribution to the achievement of the UN SDG "combating climate change" allowed SPbPU to take the 24th position in this ranking. Samara University (rank 39) was included in the ranking "peace, justice and strong institutions". The work done by leading universities to achieve the SDG "partnership for sustainable development" provided SPbPU 41st position in this ranking, IKBFU - 50th position [11].

As can be seen from the information presented above, the leading role is now played by universities that have received government support, which allows them to build their development strategies independently, relying on global trends and best practices.

In the case of regional universities, the implementation of sustainable development goals is impossible without taking into account the specific aspects of the socio-economic development of the regions. Almost every subject in the territory of the Russian Federation has its own development strategies. Therefore, it is advisable to take this direction into account and use it as a basis when developing programs for sustainable development of universities.

The Irkutsk Region is located in the southern part of Eastern Siberia on a total area of $774846 \mathrm{~km}^{2}$ (4.52\% of the Russian territory). In terms of area, the region ranks 6th among the regions of Siberia, in terms of population density - 8th. It possesses unique resources: Lake Baikal and numerous rivers, forests, reserves of minerals and oil, has an advantageous geographical position, rich recreational advantages, and its own scientific educational complex. Today, the main industries for the regional economy are forestry, woodworking, pulp and paper, mining, mechanical engineering, etc. There are 4 hydroelectric power plants in the region: The Irkutsk, Bratsk, Ust-Ilim, and Mamakan plants.

Specialists for the region are trained at Irkutsk National Research Technical University, which in 90 years has gone from a mining and metallurgical institute to a research university that ranks high in world rankings. As a multidisciplinary university, taking into account modern trends, the university today pays significant attention to the goals of sustainable development, and occupies its rightful place in the implementation of 
the "Strategy of socio-economic development of the Irkutsk Region for the period up to 2036" [12]. The fundamental task in the development of the region is education and training, creating additional conditions for the growth of talented youth and using these talents in the region for a technological breakthrough.

Based on the experience of the best universities in the world, Irkutsk National Research University has developed and is implementing a program that meets the goals of sustainable development.

The university's long-term program for sustainable development includes the following main areas:

- educational and scientific activities in the field of technosphere safety and sustainable development of the region;

- outreach activities in the field of assessing environmental and man-made risks at industrial facilities, institutions and organizations and ensuring sustainable development by minimizing risks;

- activities aimed at reducing the ecological (carbon) footprint of the university;

- creating a system of responsible attitude to waste management and recycling, especially food waste;

- creating a resource-saving system, including energy, water consumption, wastewater disposal;

- decreasing the transport footprint and environmentally responsible purchasing;

- creating environmentally sound infrastructure of the university campus.

The entire staff of the university is involved in the implementation of these areas, from the educational support staff to students and academic teaching staff.

An example of the implementation of educational and scientific activities is the creation and successful functioning of scientific consortia of departments and academic institutions. For example, the Academic Council of the University established a scientific consortium: INRTU - East Siberian Center for Medical and Ecological Research SB RAS - Irkutsk Interregional Veterinary Laboratory - to solve the problem of pharmaceutical waste that has not been investigated for the Baikal region. Pharmaceutical waste is released into the environment from livestock, forage production, large-scale dairy farms, aquaculture, poultry farms, etc.; when medicines from home first-aid kits remained unused after the completion of treatment, expired medicines purchased in excessive amount are thrown into household waste, sewage wastewater from water disposal systems of settlements and wastewater from hospitals, etc.

All students studying at the university master the discipline of "life safety" and in their design work necessarily assess the environmental consequences of the implementation of their design solutions. Students and postgraduates enrolled in the training programs of technosphere safety, construction, electric and heat power engineering, and food industry develop specific environmental protection solutions for specific economic entities of the Baikal region. In some programs, such disciplines as regional ecology (Baikal studies), methods and technologies for assessing environmental risks, environmental management and resource conservation, etc. have been introduced.

The university conducts academic competitions, scientific conferences and forums for young people, for example, "Baikal 2020", when talented youth are given grants for the implementation of environmental and social projects aimed at ensuring sustainable development of the region, campaigns to clean up small rivers, and Olkhon Island in Lake Baikal.

The university successfully implements programs on energy efficiency and resource conservation: metering devices are installed in all buildings of the university campus, information from which is monthly sent to the central computer (automatic reading of 
metering devices), which makes it possible to analyze water and energy costs of each individual building included in the university campus.

The campus hosts an annual Energy Saving Leaders competition, the main goal of which is energy and water efficiency. Students are taught to efficiently use resources at meetings of student assets, open lectures and during guided tours to the Regional Demonstration Center "Energy Saving and Energy Efficiency" located in the INRTU Technopark. A pilot project for the installation of solar power panels with a total capacity of $3 \mathrm{~kW}$ has been implemented on the territory of the university, near the building of the Technopark.

The university pays great attention to the development of research in the field of green engineering and technosphere safety of the Baikal region. It developed a project to ensure sustainable hot water supply and wastewater treatment based on renewable energy sources in the sports and recreation camp "Polytechnic", etc.

The work carried out by the university in the direction of the UN Sustainable Development Goals made it possible to become the only university in Eastern Siberia included in the Times Higher Education "University Impact Rankings 2019", ranking 301+ in the world, and to rise by 3 positions in the UI GreenMetric ranking in 2019 and rank 26 in Russia and 540 in the world. Irkutsk National Research Technical University strives to minimize its impact on the environment, is aware of the responsibility for the formation of ecological thinking among teachers and students, and implements the UN sustainable development goals within the educational process.

\section{Conclusions}

Irkutsk National Research University is consistently strengthening its position on the path to sustainable development. It works with students and staff in the framework of the educational process, project training, conducts research conferences, academic competitions, environmental campaigns, and environmental education activities based on the UN concept of sustainable development. The university also supports student research societies, whose activities are aimed at working in the field of sustainable development of the Baikal region. The university actively cooperates with the government of the Irkutsk Region in the direction of ensuring technosphere safety: the "Safety Data Sheet of the Irkutsk Region" has been developed, joint research is underway to prevent threats associated with natural phenomena, as well as in matters of ensuring the environmental safety of facilities with accumulated environmental damage. The university is preparing a roadmap for the implementation of its own strategy in this direction.

The short-term tasks are: preparation of the university's report on the sustainable development of INRTU for 2020-2021, as well as the development of a comprehensive strategy for the sustainable development of INRTU according to the SDGs. On their basis, medium-term tasks will be supplemented and updated: work on energy conservation and rational use of natural resources, drawing up programs to offset the carbon footprint, etc.

The long-term, resource-intensive and most ambitious task is the implementation of the Green Campus project, which aims to gain competitive advantages over other universities in the Russian Federation, improve the university's image and promote its internationalization, thereby creating a valorization of the educational, research and social spheres of INRTU.

Thus, the analysis of the aspects of sustainable development of Russian regional universities using the example of the Irkutsk National Research University showed that at the moment there is a gradual transition to a new model of socio-economic development of society. The general concern about the consequences of climate change and their impact on the economy as a whole and the reduction of dependence on fossil fuels confirm the need 
for a transition to the UN sustainable development strategy for all participating countries. In this process, regional universities are assigned a very important role in the formation of human capital, that is, a responsible society realizing the interconnection of the economy, society and the environment, carrying out its activities in the interests of future generations.

\section{References}

1. Transforming our world: the 2030 Agenda for Sustainable Development, https://www.un.org/

2. Murray Paul, Douglas-Dunbar Andrew, Murray Sheran, International Journal of Sustainability in Higher Education, 15(10) (2014)

3. UNESCO, Educational Trends in Perspective Analysis of the World Education Indicators, http://uis.unesco.org/

4. A European Green Deal, https://ec.europa.eu/

5. National action plan for the first stage of adaptation to climate change for the period up to 2022, http://static.government.ru/

6. Survey of Board members of Russian companies (2019), https://www.pwc.ru/ru/materials/pwc-board-survey2019-russian.pdf

7. Sustainable university of Graz, https://plattform-nachhaltigkeit.uni-graz.at/

8. University of Helsinki, https://www.helsinki.fi/

9. Sussex Estates and Facilities, https://www.sussex.ac.uk/

10. Objectives of sustainable development: the contribution of universities of the 5-100 Project, https://www.5top100.ru/

11. The Times Higher Education Impact Rankings, https://www.timeshighereducation.com/

12. Strategy of social and economic development of the Irkutsk region for the period up to 2036, https://irkobl.ru/

13. The Irkutsk national research technical University - environmental policy, https://www.istu.edu/ 